\title{
Sustainable irrigation: Alberta perspectives
}

\author{
H. Bjornlund ${ }^{1,2}$ \& W. Xu ${ }^{1}$ \\ ${ }^{1}$ University of Lethbridge, Canada \\ ${ }^{2}$ University of South Australia, Australia
}

\begin{abstract}
The problem of water scarcity is emerging in Southern Alberta, and the environment starts to feel its impact. Among 33 main stem river reaches in the South Saskatchewan River Basin (SSRB), 22 of them are rated as 'moderately impacted', five as heavily impacted, and three as degraded due to the current level of water extraction. At the same time, the region experiences significant population and economic growth. Community values and attitudes toward the environment are also changing, with increased demand for leaving more water in the rivers for improved ecosystem health and recreational benefits. In response to these transformations, the SSRB was closed in 2005 and no new applications for water licenses will be accepted. As a result, policy pressures are mounting on using existing licenses more efficiently. There is an urgent need to find ways of sharing the water already allocated and to leave more water in the rivers to meet water conservation objectives. Because it currently controls $70-80 \%$ of all allocated water within the SSRB, irrigation clearly needs to play a critical role in meeting Alberta's future water allocation objectives. For irrigation to remain sustainable it needs to be more efficient and productive with its water use and to find ways of sharing its water with the rest of the community. Otherwise, political pressure will mount for non-voluntary sharing arrangements, which could result in an unsustainable irrigation industry. Recent attempts to share irrigation water in Alberta have been subject to persistent opposition. This paper will discuss the recent development in Alberta and will explore the reasons for the opposition both from irrigators and non-irrigators. The paper is based on seven major surveys conducted during the 2006-12 period.

Keywords: sustainable irrigation, water sharing, Alberta, Canada.
\end{abstract}




\section{Introduction}

Many water scarce regions of the world are facing significant challenges meeting future increases in water demand from new and existing users while also addressing the needs of the environment. With the increased population affluence, the participation in recreational activities such as swimming, boating, fishing and golfing that directly or indirectly use water bodies is increasing. This has increased the awareness of environmental need for water and elevated the demand for leaving more water in the rivers for environmental and recreational purposes. At the same time many Basins in the world have been closed and no more applications for new water licenses are accepted. Hence, water managers and catchment stakeholders are faced with two simultaneous challenges: to reduce extraction for consumptive use so as to leave more water in the rivers, and to meet the increased demand from all sectors of the economy.

Considering that irrigation accounts for $80 \%$ of water allocations in many water scarce basins [1], it is inevitable that the irrigation sector has to play a pivotal role in meeting those two challenges. Reducing extraction and meeting future demand from new or existing users will necessarily involve a reallocation of water currently allocated for irrigation. Voluntarily or involuntarily, irrigators will have to find ways to share their allocated water with other sectors of the economy and the environment. However, reducing irrigators' access to water can have significant socio-economic impacts on irrigators as well as the communities whose livelihood depends heavily on the irrigation industry. Less water availability for irrigation could result in a reduced output from agriculture, loss of jobs, decline in land values and municipal revenues. The socio-economic impacts of such reduction will depend largely on how irrigators respond to the reduction and how the society implements it.

If irrigators respond by increasing water use efficiency and productivity or shifting to more valuable crops, then the value and volume of production might not decline and the feared impact on the community might not materialize. If government buys water back from irrigators, it might enable them to establish an alternative way of living or assist them in adjusting their farm to become more productive. If water markets are introduced to facilitate a voluntary reallocation of water, then irrigators selling part or all of their water will be compensated and new potential users will have an avenue to access water. More productive and efficient irrigators might buy water from less efficient irrigators and thereby increase overall efficiency and productivity and reduce the socio-economic impact of reducing water access for the irrigation sector.

However, attempts to reallocate water out of irrigation to meet new demand using water markets or other ways of sharing the available water have in most instances been met with opposition. It is therefore important to learn from lessons and experiences from different parts of the world. Alberta, Canada is starting to feel the impact of water scarcity. The South Saskatchewan River Basin (SSRB), the home for $65 \%$ of all irrigation in Canada, has been closed and no new applications for water licences will be accepted. To improve efficiency and productivity of water use and achieve the defined water conservation 
objectives, Alberta has implemented water trading, water planning and other water policies. Alberta therefore provides an opportunity to investigate how this process has progressed and how the policy reforms have been received by all sectors of the community. Based on a number of surveys conducted from 2006 to 2012, this paper examines how various sectors of the community perceive the ways that water should be shared, the attempts made in Alberta to share water, and investigates how irrigators have embraced water markets and efficiency and productivity improvements.

\section{The Alberta context}

Alberta is a very diverse province when it comes to water resources. The northern part is very rich in water, but it is sparsely populated and has little economic activity apart from mining. Water scarcity therefore is not a big issue. However, the mining sector, especially the oil sands, has raised serious water quality issues. The southern part is densely populated, and has a vibrant and diverse economy but water supply is more limited. This is especially true in the SSRB. By 2005 it became clear that the Basin (except for the Red Dear River in the northern part) was fully or over allocated and many river reaches started to feel the environmental impact of the current level of extraction [2]. As a consequence Alberta Environment, the provincial government department responsible for water at the time, placed a moratorium on additional surface water licenses in the southern tributaries of the Basin in 2001 [3] and closed the rest of the Basin in 2005 (except the Red Dear River) [2].

At the same time significant population and economic growth has been predicted for the SSRB: i) water demand from the non-irrigation sector could increase by $35-67 \%$ by 2021 and by $52-136 \%$ by 2046 ; ii) irrigation has the potential to expand by up to $10 \%$ and $20 \%$ in the Oldman and Bow Rivers; and iii) the population in the SSRB could increase from 1.3 million in 1996 to over two million by 2021 and more than three million by 2046 [2]. Also considering the impact of climate change the near to medium future is likely to see a significant increase in the demand for water for consumptive use as well as for leaving more water in the rivers. While Rivers are over allocated the environmental impact of this is not yet fully realised because most license holders only use a fraction of their licensed allocation. Hence, the political pressure is still not adequate to generate any drastic measures, but the problem is apparent and there is a growing understanding that failing to address the issue now might result in significantly higher economic and political cost in the future.

\subsection{Water policy and law}

Water users in Alberta hold licensed water allocations under the Water Act 1999. These licenses are under the prior allocation system, according to which license holders have access to extract water according to the seniority of their license. Non-government entities cannot hold licenses for in-stream purposes, and licenses are only issued for extractive purposes. This prevents individuals and 
NGOs from acquiring water licenses to support river flows for the benefit of the environment or recreational qualities.

Most irrigators are located within 13 irrigation districts which hold the licensed allocations. Irrigators' right to water is secured by being registered on the districts' assessment role with a defined number of acres each entitled to be supplied by a certain number of acre inches, varying from district to district but normally $15-18$ acre inches.

Water trading was introduced with the 1999 Water Act. License holders can buy, sell, or lease licensed allocations; they can also assign their access to water to another licence holder during a given season. For irrigators within districts trade is restricted under the Irrigation Districts Act, 2000 (IDA). Irrigators can trade between members of a district relatively unrestricted but trade out of districts needs the approval by a majority of irrigators in a plebiscite. Under the IDA, a district can enter into water supply contracts with non-agricultural users on an ongoing basis without permanently selling part of their licensed allocations. To do that the license has to explicitly specify that part of the water can be used for non-irrigation purposes.

In 2003 Alberta introduced its long term provincial water management strategy, the Water for Life strategy. The strategy acknowledges that the SSRB are fully or overcommitted and that drastic measures are needed to ensure environmental sustainability and to secure that the SSRB can continue to meet the need for safe and secure water for human and economic uses. The strategy relies on a $30 \%$ improvement in water use efficiency and productivity as the main method of satisfying new demand. It also relies on voluntary reallocation of water as the means to meet new demand and states that economic instruments will be used as necessary to meet the objectives. The strategy also relies on public participation in water planning processes. Water Planning and Advisory Councils within each catchment are to develop water management plans and define Water Conservation Objectives (WCO). Upon the minister's approval of the plan, a license will be issued to secure the WCO. However, this license will be issued with the priority of the date when the plan is approved. Hence they will be junior to any existing extractive licenses [4].

\subsection{History of water sharing in Alberta}

While water trading has been possible since 1999, its use has been very limited. The right to assign water licenses was used during the 2001 drought as a way of sharing the pain of reduced access to water during this period of severe drought. Senior license holders suspended their seniority so that all licenses received water on equal terms. That arrangement was agreed on as an important agricultural processor held a junior license and hence might have had to close down due to lack of water. During the drought there was also a somewhat thriving market in assignments between irrigators which significantly assisted irrigators in managing the drought [5].

Trading in licensed water allocations has been very slow with only a handful of arms-length transactions taking place [6]. A survey of irrigation district managers and board members in 2006 indicated very little support for the use of 
economic instruments such as subsidies for adopting improved irrigation technologies and water markets. Only $24 \%$ supported the use of some kind of economic instruments, $8 \%$ agreeing with transfers of licensed allocations, $15 \%$ with assignments of the right to use water, and $21 \%$ with subsidizing farmers to become more efficient [7]. However, the same survey indicated that only $26 \%$ agreed that water saved through the adoption of more efficient technology should be used to meet the need of the environment while $69 \%$ agreed that saved water should be used to put dry land under irrigation [8]. While the survey suggests that there has been significant improvements in water use efficiency among irrigators suggesting that the WFL objective of more efficient and productive use of water might be achieved $[9,10]$, there is little indication that the saved water will be used to meet new demand from other economic sectors and the environment.

A survey of both district and private irrigators in 2006 tried to elicit irrigators' willingness to participate in water markets if it would make economic sense. An almost equal number, approximately $37 \%$ of private and district irrigators indicated they would be willing to sell an assignment of the use of their water for one year. But when it came to permanently selling their licensed allocation, a much higher percentage of private irrigators, $22 \%$, compared to district irrigators $7 \%$, would do so. This likely reflects that in general private irrigators has a much larger proportion of their land in dry land farming with irrigation being a small proportion of their farm business mainly producing feed for their cattle production. Finally, irrigators were asked if they would consider buying additional licensed allocation to expand their irrigated area, $42 \%$ of private irrigators indicated that they would compared to $61 \%$ of district irrigators. This is likely to reflect that district irrigators derive most of their production from intensive irrigation with very little dry land farming [11].

In 2007 the first major transfer of 1,500 acre feet took place between the Western Irrigation District and the municipality of Rocky View for the development of a shopping mall, race course and casino north of Calgary. This transfer was needed as the City of Calgary refused to supply the development because it was outside its legal control and despite the fact that it has plenty of water and existing infrastructure to supply the water. The transfer was met with significant opposition from environmental groups, the City of Calgary and others, but was eventually approved.

Since the deal involved the transfer of water out of a district a plebiscite was required. Despite the fact that the developer would pay record breaking prices for the water allowing the WID to invest in converting an inefficient canal to a pipeline and thereby saving more water than they sold, irrigators only approved the transfer with a narrow margin. Research by Lafreniere et al. [12] suggests that WID irrigators voted yes or no for different reasons and that the information material provided by the WID leading up to the plebiscite did not take this into account. One group of irrigators voted yes because they knew that the government wanted the deal to go through and were worried that if they voted no, the government would simply take the water away; a second group voted yes because the proceed was invested so that more water would be save than was 
sold. One group voted no because the transfer was only necessary because the City of Calgary would not provide the water, a solution which would have been far more efficient. A second group voted no because they did not think the proceeds from the sale would be spent in an appropriate manner which would benefit all members.

Recognizing the level of opposition among irrigators to relinquishing the long term control over water, and understanding the need to show a willingness to share the district's excess water, district leaders are pursuing alternative ways of sharing water by entering into water supply agreements with municipalities and industries in need of water. In many instances this requires a license amendment under the Irrigation District Act. Several districts have got such an amendment in the past. However, the recent wave of applications has been held up due to opposition to such amendments in particular from the environmental lobby groups which argue that such supply agreements would circumvent the rigorous environmental impact assessment required for the transfer of licensed water allocations [13].

\section{The future of water sharing in Alberta}

The above discussions suggest that progress is being made in achieving improved water use efficiency and productivity thereby reducing water use. However, there is limited evidence that the saved water will be shared with other sectors of the society. The use of economic instruments is not widely accepted among irrigators and the most recent major transfer indicates a reluctance to permanently sell part of the districts licensed allocation. Ongoing research is investigating this reluctance and the low level of market participation among individual irrigators. Two surveys of irrigators were conducted in late 2011. One involved 275 irrigators across all 13 irrigation district to follow up on the qualitative analysis [12] to gain a better understanding of the factors influencing irrigators voting pattern in plebiscites to transfer water out of districts [14]. A second involved 319 private and district irrigators across the SSRB to investigate irrigators trading activities over the last five years and their intended trade over the next five years [15].

\subsection{Actual and intended market participation}

In the 2011 survey we asked irrigators about their actual participation in water trading in the last five years and how likely they were to participate in water trading over the next five years (table 1).

There is still a very low level of activity in the market for licensed allocations, especially in actual selling, with only 1 and $2 \%$ respectively having sold licensed allocations over the last five years. There is a higher level of participation in buying, especially among district irrigators. This reflects a drive within many districts to expand their irrigated area closer to their total assessed area. Historically districts have used less than half their allocated water during normal supply years. To increase the irrigated area, district irrigators have to agree on 
Table 1: $\quad$ Past and intended water trading participation.

\begin{tabular}{|l|l|l|l|l|}
\hline Trading type & \multicolumn{2}{|l|}{ Last five years } & \multicolumn{2}{l|}{ Next five years } \\
\hline & $\begin{array}{l}\text { District } \\
\text { Irrigators }\end{array}$ & $\begin{array}{l}\text { Private } \\
\text { Irrigators }\end{array}$ & $\begin{array}{l}\text { District } \\
\text { Irrigators }\end{array}$ & $\begin{array}{l}\text { Private } \\
\text { Irrigators }\end{array}$ \\
\hline Lease out water & $3 \%$ & $2 \%$ & $8 \%$ & $15 \%$ \\
\hline Leased water & $17 \%$ & $8 \%$ & $38 \%$ & $30 \%$ \\
\hline Sell licensed allocation & $2 \%$ & $1 \%$ & $4 \%$ & $16 \%$ \\
\hline Buy licensed allocations & $28 \%$ & $8 \%$ & $43 \%$ & $30 \%$ \\
\hline $\begin{array}{l}\text { 1 Respondents were asked about the likelihood of them undertaking each of the } \\
\text { four trading activities on a 1 to 7 scale from highly unlikely to highly likely. }\end{array}$ \\
The percentage reported here are those rating each trading activity 5-7. \\
\hline
\end{tabular}

this in a plebiscite. Some districts have just recently gone through this process while others are currently in the process. Irrigators can then buy the right to expand their irrigated area and get a secure supply of water for that area. The irrigators pay the district for the right and often it is part of the plebiscite to decide how the revenue from the sale is going to be spent. In most instances the money is used to improve the communal irrigation infrastructure to become more efficient or to build new infrastructure to supply the new land. Irrigators have been reluctant to expand their irrigated area as they want absolute certainty that they will have water enough during all years. However, with growing pressure on sharing their water with new users there is an increasing fear that if they do not start using more of it the government might force them to share it.

There has also been an increase in the use of short term leasing of water, especially among district irrigators. For the intention to participate in water trading in the next five years, the number is considerably higher than the number indicating past actual trade both for the leases and permanent transfers of licensed allocation. This is likely to reflect two things. First, the figures for intension include all those rating the likelihood five to seven that they consider it somewhat likely rather than unlikely. Secondly, water trading is increasingly discussed in the policy debate. The likelihood of irrigators leasing out some of their water or selling part of their licensed allocation in the next five years is considerably larger among private irrigators than district irrigators. This is likely to reflect that private irrigators are not as dependent on irrigation as district irrigators. For private irrigators, it is mainly supplementary and to secure feed for their feet-lot or cow-calf operations, which is relatively easy to be substituted by buying feed. Also, private irrigators have the ability to negotiate a sale of their licensed allocation which then only needs the approval of the relevant government department. On the other hand district irrigators have to go through a plebiscite to sell all or part of their licensed allocations to buyers outside the district.

\subsection{The role of irrigation districts}

Irrigation Districts have the largest and most senior licenses and have traditionally not used all their water. Most districts have extensive supply 
infrastructure which can be improved to save substantial volumes of water. Hence, the irrigation districts have the greatest potential to make water available to meet new demand. Districts have in the past been willing to share their water with neighbouring towns and new industries. To expand that capacity, districts are in the process of amending their licenses. However, as discussed the one attempt of a major transfer caused a lot of controversy among irrigators in the affected district. That experience illustrates the importance of understanding what influences irrigators voting so that district when proposing such transfers can provide more appropriate information.

The previous qualitative research into what caused some irrigators to vote yes and others no in the 2007 plebiscite in the Western Irrigation Districts [12] identified six attributes: i) the purpose of the agreement: i.e., to supply water to the environment, municipal use or to expand irrigation; ii) the price paid: i.e., at market price, above market price, or at a market record; iii) proximity to personal benefits: i.e., the proceed from the sale would go to upgrade a part of the infrastructure on which the respondents directly depend, or a part on which the respondents do not personally depend; iv) water savings: i.e., the proceed from the sale will be used to improve water use efficiency resulting in water savings equivalent to all the water sold or half the water sold; v) government involvement: i.e., the government wants the trade approved or the government does not care either way; and vi) environmental efficiency: i.e., the district is the closest and most efficient way to meet the new demand or the district is not the most efficient way of meeting the new demand. Each respondent was asked to rate how likely they would be to vote yes to 16 proposed transfers (using a 1-20 scale) with different levels of the six attributes [14]. Conjoint analysis was applied to the respondents who would consider voting yes depending on the attributes. Fourteen per cent of the respondents said they would vote no regardless of the attributes, these were label 'Nay-Sayers' and are discussed in more detail in [16]. Six irrigators said they would vote yes regardless of the attributes.

The respondents considering voting yes dependent on the attributes were segmented using a cluster analysis based on their preference scores from the conjoint analysis. Five segments were identified dependent on which attribute of the transfer was most likely to influence them to vote yes: i) 'Water Savers' consisted of $25 \%$ of all respondents. They were most likely to vote yes if the proceed would be spent so that all the water sold would be saved; ii) 'Greenies' consisted of $17 \%$ of the respondents. They were most likely to vote yes if the water sold went to the environment; iii) 'Municipal Friends' also consisted of $17 \%$ of respondents. This group was most likely to vote yes if the water would be used to supply municipal needs but also had the highest rating on the government wanting the transfer to be approved; iv) 'Personal Gainers' consisted of $15 \%$ of the respondents. They were most likely to vote yes if they would personally gain from the way the proceeds were spent and that the price paid was at a market record; and v) 'Efficiency Savers' made up $8 \%$ of the respondents. This group was most likely to vote yes if the transfer was the most efficient way of meeting the new demand [14]. 


\subsection{Non-irrigators perspectives}

As discussed there have been significant oppositions to recent attempts to share the water licenses held by Irrigation Districts. To improve our understanding of the opposition two surveys were carried out exploring how the general public perceives that water sharing should take place [17-20].

Four communities were surveyed across the SSRB: i) two in the southern part dependent on the Oldman and St. Mary Rivers which have experienced water scarcity and reduced access to water in the past and feel the emerging impact of environmental degradation; and ii) two in the northern part dependent on the Bow River which have been far less exposed to water scarcity and the impact of environmental degradation. The four communities were also selected to represent four points on the rural-urban gradient, from the largest city Calgary with little dependence on irrigation to a group of four small irrigation communities (Raymond, McGrath, Tabor and Sterling, RTMS) totally dependent on irrigation for economic activity and jobs.

The research explored peoples' policy preferences for water sharing, how they change depending on the level of water scarcity and resource dependence as well as what influence the preferences once location is controlled for. Respondents were asked to rate their level of agreement with ten statements reflecting policy options currently being discussed in Alberta. The policies reflect three different policy orientations: i) policies giving strong powers to the government; ii) policies protecting the environment; and iii) policies protecting current license holders [19].

All ten policy statements were rated significantly different across the four regions suggesting that local context matters. For five of the ten statements the level of agreement followed the rural to urban gradient (Calgary, Lethbridge, Strathmore, RTMS). For the other five policy statements the level of agreement followed the scarcity gradient from the scarcer South to the less scarce north. Based on the respondents' level of agreement with 40 statements reflecting the values they hold toward water, the environment and irrigation, a multivariate factor analysis was used to establish four value constructs reflecting the respondents perception of: i) pro environmental values; ii) value water as a commodity; iii) value irrigation as an important industry in Alberta, and iv) value water for domestic use.

While the above discussion suggests that location influence policy preferences, regression analysis were used to identify other influencing factors once location is controlled for. This analysis shows that there are clear associations between peoples' values and attitudes and their policy preferences [19]: i) people with pro-environmental values support policies giving strong powers to the government and those protecting the environment while they oppose policies protecting the interest of current license holder; ii) people valuing water as a commodity oppose policies giving strong powers to the government but are supportive of policies protecting the right of current license holders; iii) people valuing irrigation supports policies protecting the right of 
current license holders; and iv) people valuing water for domestic use support policies giving strong powers to the government.

The literature on what influence environmental values and hence policy preferences suggest that that socio-demographic variables, rather than place of residence are important (Jones et al. [21]; Dietz et al. [22]). This study partly supports these findings: i) younger people support environmental protection; ii) older people support a strong government; iii) women support environmental protection; iv) people being raised in a rural setting are less likely to support a strong government; v) people with a tertiary education support a strong government and environmental protection; vi) people having a bachelor's degree show no support for irrigators' rights; vii) people with higher income support a strong government and show no support for the right of existing license holders.

The importance of peoples' direct involvement with the environment is highlighted by the findings that: i) people actively participating in water-based recreation are more in support of giving strong powers to the government and protecting the environment; ii) people working in recreation support policies protecting the environment; iii) people working in primary industries oppose policies protecting the environment; iv) members of Water Planning and Advisory Councils or watershed stewardship groups oppose policies giving a strong role to the government; v) members of conservation groups oppose policies protecting current license holder but are supportive of giving a strong role to the government. This research highlights that the impacts (apart from women showing a higher preference for policies protecting the environment) vary between the four locations tested, hence stressing that context and geography matters.

\section{Conclusions}

This paper has discussed the need to share the water currently allocated to the irrigation sector, the irrigators' willingness to participate in such sharing, and non-irrigators policy preferences for water sharing. There is evidence to suggest that there is a growing willingness to consider participating in market transactions. Private irrigators with their own license have a greater ability to make such arrangement in their own right and are less depending on irrigation, because irrigated production constitutes a smaller proportion of their farm business. On the other hand, district irrigators have a limited capacity to participate as a transfer of water to outside a district needs to be approved by a majority of irrigators within the district. The first major example of such a collective transfer of a small part a districts' licensed allocation, even though the proceeds from the sale would be used to improve leaking infrastructure which would result in water savings larger than the volume sold, was only approved by a narrow margin in the plebiscite.

Irrigators' decision to vote yes or no in a plebiscite seems to be influenced by what the new use of the water will be, the price paid, whether the transfer is the most efficient way to satisfy the new demand, and how the proceed will be spent by the district. Failing to take these factors into account by the managers of 
the Western Irrigation District, when marketing the transfer to its members, could be a direct reason for the narrow approval of the transfer.

The voting public's policy preferences for water sharing are very much content specific and geographically contingent. People living in more water stressed part and in more resource dependent communities have significantly different opinions about how water should be shared. Peoples' involvement with water resources through recreation, work or membership of organizations also influences their policy preferences. Finally peoples' values and attitudes towards the environment, water and the irrigation sector also have a strong influence. These findings suggest what factors policy makers and water managers should take into account when designing and implementing policies or instruments for water sharing.

\section{References}

[1] Postel, S. 1999. Pillar of Sand: Can the Irrigation Miracle Last? W.W. Norton.

[2] Alberta Environment 2005. "Background Information for Public Consultation on the South Saskatchewan River Basin's Draft Water Management." Edmonton.

[3] Alberta Environment. 2003. Ministry of Environment. "Summary, SSRB Background Studies." Edmonton.

[4] Bjornlund, H. (2010): The Competition for Water: Striking a Balance among Social, Environmental and Economic Needs. Commentary No 302: Governance and Public Institution, C.D. Howe Institute, Toronto.

[5] Nicol, L. and Klein, K. (2006): Water Market Characteristics: Results from a Survey of Southern Alberta Irrigators. Canadian Water Res. Journal 31,2, 91-104.

[6] Nicol, L., Klein, K., and Bjornlund, H. (2008): Permanent Transfers of water rights: A study of the southern Alberta market. Prairie Forum 33(2), 341-56.

[7] Bjornlund, H.; Nicol, L. and Klein, K. (2007): Challenges in Implementing Economic Instruments to Manage Irrigation Water on Farms in Southern Alberta. Journal of Agricultural Water Management 92, 131-141.

[8] Bjornlund, H. Nicol, L. and Klein, K. (2008): Implementing Alberta's Water for Life Strategy: An Irrigation Industry Perspective. Prairie Forum 33(1), 167-190.

[9] Bjornlund, H.; Nicol, L. and Klein, K. (2009): The Adoption of Improved Irrigation Technology and Management Practices - A Study of Two Irrigation Districts in Alberta, Canada. Journal of Agricultural Water Management 96, 121-131.

[10] Nicol, L.; Bjornlund, H. and Klein, K. (2010): Private Irrigators in Southern Alberta: A survey of the Adoption of Improved Irrigation Technologies and Management Practices. Canadian Journal of Water Resources, 35(3), 339350 . 
[11] Bjornlund, H. Nicol, L. and Klein, K. (2008): Economic Instrument and Irrigation Water Management - A Comparative Study of Private and District Irrigators in Alberta, Canada. In Esteve, Y.V.; Brebbia, C.A. and Rico, C.P Eds. Sustainable Irrigation Management, Technologies and Policies II. WIT Press, Southampton. Transaction on Ecology and the Environment, Volume 112, 3-14.

[12] Lafreniere, K., Deshpande, S.; Bjornlund, H.; Hunter, G (Forthcoming).: The decision making process for social issue behaviours: A stakeholders perspective. Journal of Environmental Management.

[13] Banks, N. and Kwasniak, A. 2005. The St. Mary's Irrigation District License Ammendment Decisions: Irrigation District as a Law onto Themselves. Journal of Environmental Law and Practice 16(1), 1-18.

[14] Lafreniere, K., Deshpande, S.; Bjornlund (forthcoming ): Using Conjoint Analysis to Assess Irrigators' Preferences of Water Transfers in Alberta, Canada. In preparation for Journal of Society and natural Resources.

[15] Hall, M.; Bjornlund, H. and Wei, X. 2012: Exploring Private and District Irrigators' Perceptions towards Water Trading in the South Saskatchewan River Basin. SAREC Report 2012-1, University of Lethbridge.

[16] Lafreniere, K.; Bjornlund, H. and Deshpande, S. 2012. Against the grain: Segmenting and profiling irrigators opposed to water transfers in Alberta, Canada. In Bjornlund et al. Eds. Sustainable Irrigation, WIT Press, Southampton, UK.

[17] Russenberger, M.; Bjornlund, H. and Xu, W. 2012. Exploring links between policy preferences for water reallocation and beliefs, values, attitudes and social norms in Alberta, Canada. In Pepper, D. and Brebbia, V. Eds. Water and Society, WITPress, Southampton, 107-118.

[18] Russenberger, M.; Bjornlund, H. and $\mathrm{Xu}, \mathrm{W}$. 2011. Exploring the links between values, beliefs, attitudes and social norms and policy preferences for water reallocation in Southern Alberta, Canada. Proceedings from the XIV World Water Congress, Recife, Brazil, September.

[19] Bjornlund, H.; Xu, W.; Zuo, A and Wheeler, S. 2012. Resource dependence and water scarcity; how do they influence policy preferences for water sharing? Presented at the IWREC Conference as part of Stockholm Water Week. August.

[20] Bjornlund, H.; Parrack, C. and DeLoe, R. forthcoming. Segmenting residents of southern Alberta for improved understanding of policy preferences for water reallocation. Submitted to Journal of Society and Natural Resources.

[21] Jones, R., Fly, J. and Cordell, H. 1999. 'How Green is My Valley? Tracking Rural and Urban Environmentalism in the Southern Appalachian Ecoregion, Rural Sociology, 64(3), 482-499.

[22] Dietz, T, Fitzgerald, A, and Shwom, R. 2005. Environmental Values, Annual Review of Environment and Resources, 30, 335-372. 